\title{
PENGEMBANGAN BAHAN AJAR DAN PENILAIAN OTENTIK MATA KULIAH PENDIDIKAN IPA SEKOLAH DASAR
}

\author{
Heru Purnomo ${ }^{1}$, Arrofa Acesta ${ }^{2}$ \\ Fakultas Keguruan dan Ilmu Pendidikan, Universitas Kuningan \\ 1herupurnomo809@gmail.com; ${ }^{2}$ arrofa_acesta@yahoo.com
}

\begin{abstract}
This study aims to produce teaching materials and assessment of authentic courses of education IPA in Elementary School decent and effective. This research is a research and development. consisting of nine stages, namely: (1) preliminary study, (2) planning, (3) initial product development, (4) initial test, (5) revision to compose the main product, (6) field trial, (7) ) revisions to improve the product of field trial results, (8) field implementation tests, and (9) final product revisions. The results of the study as follows. (1) Feasibility assessment of IPA material experts and science evaluation experts with good criteria with an average rating of 3.8 , assessment of IPA materials with an average rating of 4.08, Trial is limited to Good criteria and field implementation trials with good criteria. The effectiveness of product development of gain score calculation know knowledge aspect (knowledge) obtained index of gain equal to 0,71 with High category, Field test result which done in three classes got average result as follows, Student who give Very Good response 27, 2\%, good student response with average percentage 54,91\%, Student Response with Good enough category 16,27\%, while for Student response with Less category equal to 0,66\% and Less once $0,99 \%$.
\end{abstract}

Keywords: Instructional Materials, Authentic Assessment, Science Education SD.

\section{PENDAHULUAN}

Pendidikan merupakan kebutuhan yang harus dipenuhi oleh manusia dalam mengembangkan kemapuan yang dimilikinya, dengan pendidikan manusia dapat belajar untuk memperbaiki dan mengembangkan potensi yang ada pada dirinya. Pendidikan berperan dalam memperbaiki, meneruskan dan menurunkan pengetahuan dari generasi yang lalu ke generasi berikutnya. Dengan pendidikan diharapkan dapat menghasilkan sumber daya manusia yang berkualitas yang dapat mengembangkan ilmu pengetahuan dan potensi yang dimiliki manusia sehingga menjadi manusia yang relatif lebih baik, berbudaya, dan manusiawi.

Perguruan tinggi adalah salah satu lembaga yang disediakan oleh pemerintah untuk mewadahi mahasiswa dalam mengembangkan kemampuan yang dimiliki secara formal untuk memperoleh pendidikan yang lebih baik. Sebelum menempuh pendidikan di perguruan tinggi mahasiswa diwajibkan harus menyelesaikan terlebih dahulu pendidikannya di sekolah menengah atas (SMA). Berbeda dengan di sekolah menengah tingkat atas, di perguruan tinggi dikhususkan untuk mengambil penjurusan sesuai dengan bakat, minat dan potensi yang dimiliki oleh mahasiswa itu sendiri, dimana pembelajaran di perguruan tinggi memberikan gambaran yang jelas tentang hasil kompetensi yang akan dicapai oleh mahasiswa.

Program studi PGSD adalah salah satu penjurusan di tingkat perguruan tinggi yang di buka untuk mewadahi pendidikan yang lebih spesifik dalam pendidikan keguruan, khususnya bagi para calon mahasiswa yang mempunyai keinginan kuat dalam 
mengembangkan bakat, minat dan potensinya menjadi seorang calon guru sekolah dasar yang profesional sesuai dengan perkembangan kebutuhan yang ada dilapangan saat ini. Di perguruan tinggi khususnya prodi PGSD Berbagai mata kuliah wajib yang harus diambil oleh setiap mahasiswa program studi pendikan guru sekolah dasar, salah satu mata kuliah wajib tersebut adalah Pendidikan IPA SD.

Menurut Martin, R \& Sexton (2005: 10), menyatakan bahwa "The word scaince originates from the latin word scaintie, meaning "knowledge", as in possessing knowledge istead of misunder standing or being ignorant"'. Sain berasal dari kata scaince yang diartikan "pengetahuan" bagaimana menguasai pengetahuan yang terjadi pada kehidupan sehari-hari agar dapat mengetahui aspek-aspek yang ada di dunia baik alam, tumbuhan dan manusia.

Menurut Mc. Neill dan Krajcik (Manokore \& Williams, 2012: 2) bahwa pembelajaran sains harus ditunjang dengan kegiatan diskusi ilmiah sehingga memungkinkan peserta didik mampu mengungkapkan pendapat dan kesimpulannya (inference) dengan disertai bukti-bukti dan fakta ilmiah yang dapat dipertanggungjawabkan.

Mata kuliah Pendidikan IPA dimaksudkan untuk memberikan pemahaman lebih tentang prinsip-prinsip dasar pembelajaran IPA Di SD yang berhubungan dengan model-model pembelajaran IPA di SD, penilaian portofolio,dan portofolio dalam pembelajaran IPA di SD melalui penerapan berbagai modelmodel pembelajaran dan simulasi mengajar IPA di SD, akan tetapi ketersediaan bahan ajar pendidikan IPA SD yang diperuntukan untuk mahasiswa PGSD masih sangat terbatas dalam kontesk isi bahan ajar.
Kunandar (2013: 24-25) mendeskripsikan karakteristik bahan ajar/materi pembelajaran yaitu.

1) Menggembangkan keseimbangan antara pengembangan sikap spiritual dan sosial, rasa ingin tahu, kreatifitas, kerja sama dengan kemampuan intelektual dan psikomotorik.

2) Sekolah merupakan bagian dari masyarakat yang memberikan pengalaman terencana dimana peserta didik menerapkan apa yang dipelajari di sekolah kemasyarakat dan manfaat pada masyarakat sebagai sumber belajar.

3) Menggembangkan sikap, pengetahuan dan keterampilan serta menerapkan dalam berbagai situasi di sekolah dan masyarakat.

4) Memberikan waktu yang cukup leluasa untuk menggembangkan berbagai sikap, pengetahuan dan keterampilan.

5) Kompetensi dinyatakan dalam kopetensi inti kelas yang dirinci lebih lanjut dalam kompetensi dasar mata pelajaran.

6) Kompetensi inti kelas menjadi unsur pengorganisasian (organizing element) kompetensi dasar, dimana semua kompetensi dasar dan proses pembelajaran dikembangkan untuk mencapai kompetensi yang dinyatakan dalam kompetensi inti.

7) Kompetensi dasar dikembangkan berdasarkan pada prinsip akumulatif, saling memperkuat (reinforced) dan memperkaya (enriched) antar mata pelajaran dan jenjang pendidikan (organisasi horisontal dan vertikal).

Padahal bahan ajar merupakan salah satu instrumen yang vital bagi proses pembelajaran selama perkuliahan untuk membatu mahasiswa selama perkuliahan mengenai materi apa yang disampaikan. Dijelaskan 
Menurut Dick \& Carey (2009: 230) bahan ajar adalah

The instructional materials contains the content.... .includes materials for major objectives and the terminal objective, and any materials for anhancing memory and transfer... refer to any preexisting materials that are being incorporated, as well as to those materials that will be specifically develoved for the objectives...include information thet the learner will use to guide their progress through the instruction.

Berdasarkan berbagai teori yang uraian di atas dapat disimpulkan bahwa bahan ajar adalah segala bahan materi atau isi pembelajaran yang harus dikuasai peserta didik untuk menunjang pencapaian kompetensi peserta didik yang guna membantu dalam pelaksanaan kegiatan proses pembelajaran. Masih terdapat keterbatasan yang ada pada bahan ajar sekarang ini, seperti kajian yang ada masih sangat tinggi seperti konsep dasar yang ada masih konsep-konsep murni dari pendidikan IPA, padahal keberadaan materi kuliah pendidikan IPA SD lebih bedasarkan pada konsep-konsep dan aplikasi materi yang merujuk pada pembelajaran di sekolah dasar, seharusnya bahan ajar yang digunakan di jurusan PGSD lebih merujuk pada pembelajaran IPA apa yang ada disekolah dasar, sehingga bisa membekali para mahasiswa sebagai calon guru sekolah dasar untuk dapat digunakan dan diaplikasikan langsung di sekolah dasar kelak ketika mereka sudah mengajar di sekolah dasar.

Pada bahan ajar terdapat instrumen penilaian pendidikan IPA yang dirancang guna untuk mengetahui ketercapaian mahasiswa selama proses perkuliahan mengacu pada tiga aspek (otentik assessment), yaitu sikap (attitude), pengetahuan (knowledge), keterampilan (skill). Penilaian otentik merupakan penilaian yang dilakukan secara komperhensif untuk menilai mulai dari masukan (input), proses dan keluaran (output) pembelajaran (Permendikbud, 2013: 2). Menurut Nitko \& Brookhart (2007: 253) mengemukakan bahwa "authentic assesment usually means presenting student with tasks that are directly meaningfull to their education instead of indirectly meaningful."

Pada kenyataanya instrumen penilaian yang ada pada saat ini belum mengakomodir tentang otentik assessment tersebut, Padahal ketiga aspek ini sangat penting dalam melihat penguasaan mahasiswa dalam proses perkuliahan. Dijelaskan menurut Morrison (2012: 160) ciri-ciri penilaian otentik yaitu.

1) Menggunakan sejumlah cara yang berbeda untuk menentukan prestasi anak dan apa yang mereka ketahui dan mampu melakukan.

2) Mempertimbankan kebutuhan khusus menyangkut bahasa, budaya dan kebutuhan khusus lainya.

3) Berkelanjutan sepanjang tahun pelajaran.

4) Menilai anak dan karya mereka yang sebenarnya dengan contoh karya, portofolio, performa, proyek, jurnal, percobaan, dan observasi guru.

5) Menilai anak secara menyeluruh, bukan hanya dari penguasaan keterampilan.

6) Merupakan dari proses belajar.

7) Berdasarkan kurikulum, anak dinilai berdasarkan apa yang mereka pelajari dan kerjakan.

8) Merupakan proses kerja sama melibatkan anak, guru, orangtua, dan profesi lainya; tujuanya adalah membuat penilaian berpusat pada anak. 
Berbagai aspek sangat penting dikembangkan, Seperti aspek sikap dalam proses pembelajaran mata Kuliah pendidikan IPA karena dengan menggembangkan aspek sikap dapat memberikan pandangan terhadap sikap yang positif mahasiswa selama perkuliahan. Aspek pengetahuan (knowledge), knowledge dapat memberikan gambaran dosen untuk mengukur tingkat kemampuan pencapaian mahasiswa atas penguasaan konsep. Aspek keterampilan (skill) untuk melihat kemampuan mahasiswa dalam mengembangkan keterampilan mengajar dan mengaplikasikan konsep yang sudah diperoleh selama perkuliahan seperti melakukan percobaan- percobaan IPA SD dan melakukan simulasi mengajar IPA di Sekolah dasar dengan baik dan benar. Kebutuhan akan hadirnya bahan ajar dan penilaian otentik mata kuliah pembelajaran IPA sekolah dasar sangat dibutuhkan untuk memberikan bahan ajar yang sesuai dengan kebutuhan kompetensi yang diharapkan diperguruan tinggi khususnya mata kuliah pendidikan IPA di PGSD. Adapun Tujuan penelitian dan pengembangan penelitian ini adalah

1. Untuk menghasilkan bahan ajar dan instrumen penilaian otetik pendidikan IPA sekolah dasar yang layak diperguruan tinggi program studi pendidikan guru SD.

2. Dapat mengetahui keefektifan bahan ajar dan penilaian otentik pendidikan IPA di PGSD ditinjau dari penguasaan konsep, sikap dan keterampilan proses.

\section{METODE PENELITIAN}

Penelitian yang dilaksanakan ini merupakan penelitian pengembangan atau research and development. Dijelaskan Borg \& Gall (1983: 772) penelitian pengembangan yaitu penelitian yang berorentasi untuk menggembangkan, dan memvalidasi produkproduk yang digunakan dalam penelitian. Model pengembangan yang digunakan dalam penelitian ini diadopsi dari model rancangan pengembangan dari Borg and Gall (1983: 775).

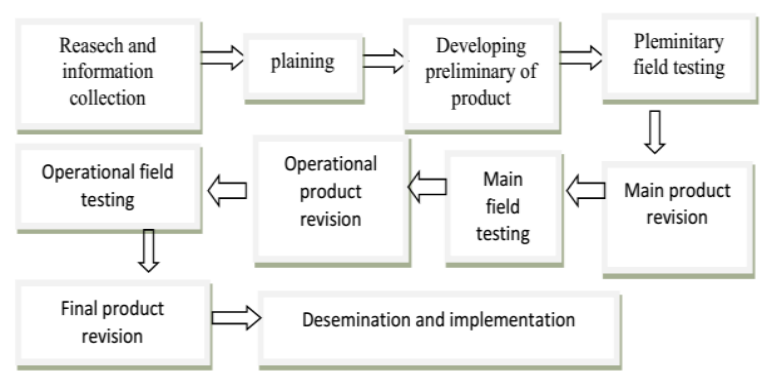

Gambar 1. Model Pengembangan Borg, .R \& Gall, M.D. (1983:775)

Penelitian ini merancang dan memodifikasi model pengembangan ke dalam 9 tahap dari 10 tahapan yang dikemukakan oleh Borg \& Gall.

1. Studi Pendahuluan

2. Perencanaan (Planning)

3. Pengembangan produk awal

4. Uji coba awal

5. Revisi untuk menyusun produk utama

6. Uji coba lapangan (main field testing)

7. Revisi untuk menyempurnakan produk hasil uji coba lapangan (oprational product testing).

8. Uji pelaksanaan lapangan (Operational field testing)

9. Revisi produk final (final product rivision)

\section{Desain Uji Coba Produk}

Uji coba dilakukan untuk mengetahui kelayakan dan efektifitas bahan ajar dan instrumen penilaian otentik IPA sekolah dasar di PGSD Universitas Kuningan. Dengan bantuan ahli materi dan ahli penilaian otentik pendidikan IPA sekolah dasar untuk meneliti pengembangan bahan ajar dan penilaian 
otentik pendidikan IPA sekolah dasar yang sedang di kembangkan.

a. Uji ahli (expert judgment)

Sebelum produk diujicobakan, produk yang dikembangkan harus divalidasi oleh ahli penilai di bidangnya agar produk ini mempunyai jaminan layak untuk diuji cobakan kepada subjek uji coba.

b. Uji coba terbatas

Uji coba awal (terbatas/ kelompok) dilakukan dengan memilih kelas mahasiwa secara acak dan menggunakan produk yang dikembangkan selama kegiatan proses perkuliahan.

c. Uji coba produk lapangan

Pada perlakuan uji coba lapangan oprasional ini dilakukan seluruh mahasiswa di tiga kelas. Selanjutnya hasil data tersebut dianalisis untuk menyusun produk final.

\section{Instrumen \& Teknik Analisis Data}

Teknik pengumpulan data Instrumen yang digunakan dalam penelitian ini adalah dalam bentuk tes dan non-tes yang berupa wawancara, observasi, angket dan validasi para pakar atau ahli untuk mengukur tingkat kelayakan bahan ajar dan instrumen penilaian otentik pendidikan IPA sekolah dasar sesuai dengan kebutuhanya

a. Analisis kelayakan atau hasil validasi ahli dan penilaian guru. Data yang diperoleh berdasarkan kuisioner dianalisis mengunakan teknik statistik deskriptif berdasarkan masing-masing variabel. . Konversi nilai skala 5 dapat dilihat pada tabel 1 yang diadaptasi dari Widoyoko (2010: 238)
Tabel 1. Konversi Skor 5

\begin{tabular}{|c|c|c|c|}
\hline \multirow{2}{*}{\multicolumn{2}{|c|}{$\begin{array}{c}\text { Nilai } \\
\text { Kreteria }\end{array}$}} & \multicolumn{2}{|l|}{ Skor } \\
\hline & & Rumus & Perhitungan \\
\hline A & SANGAT BAIK & $\mathrm{X}>\mathrm{Xi}+1,80 \mathrm{SBI}$ & $\mathrm{X}>4,20$ \\
\hline B & BAIK & $\mathrm{Xi}+0,60 \mathrm{SBi}<\mathrm{X} \leq \mathrm{Xi}+1,80 \mathrm{Sbi}$ & $3,40<\mathrm{X} \leq 4,20$ \\
\hline $\mathrm{C}$ & CUKUP & $\mathrm{Xi}-0,60 \mathrm{SBi}<\mathrm{X} \leq \mathrm{Xi}+1,60 \mathrm{Sbi}$ & $2,60<\mathrm{X} \leq 3,40$ \\
\hline $\mathrm{D}$ & TIDAK BAIK & $\mathrm{Xi}-1,80 \mathrm{SBi}<\mathrm{X} \leq \mathrm{Xi}+0,60 \mathrm{Sbi}$ & $1,80<\mathrm{X} \leq 2,60$ \\
\hline E & $\begin{array}{ll}\text { SANGAT } & \text { TIDAK } \\
\text { BAIK } & \\
\end{array}$ & $\mathrm{X} \leq \mathrm{Xi}-1,80 \mathrm{SBI}$ & $\mathrm{X} \leq 1,80$ \\
\hline \multicolumn{4}{|c|}{ Rerata ideal $(\mathrm{Xi}) \quad=1 / 2($ skor maksimal ideal + minimal ideal $)$} \\
\hline \multicolumn{2}{|c|}{$\begin{array}{l}\text { Simpanan baku ideal (SBi } \\
\text { Skor yang diperoleh }(\mathrm{X})\end{array}$} & \multicolumn{2}{|c|}{$=1 / 6($ skor maksimal - skor minimal $)$} \\
\hline
\end{tabular}

1) Skor 5 diberi kreteria Sangat baik

2) Skor 4 diberi kreteria Baik

3) Skor 3 diberi kreteria Cukup

4) Skor 2 diberi kreteria Kurang baik

5) Skor 1 diberi kreteria Sangat tidak baik

b. Analisis keefekifan

Teknik analisis data untuk mengetahui efektifitas produk pengembangan dengan pretest dan post-tes untuk menggukur aspek kemampuan pengetahuan (knowledge) dan observasi untuk mengetahui aspek keterampilan (skill) dan aspek sikap (attitude), kemudian melakukan perhitungan menggunakan teknik normalized gain score atau normalisasi skor gain $\langle\mathrm{g}\rangle$. Langkahlangkah perhitungan yang dilakukan adalah sebagai berikut.

1) Gain ternormalisasi dihitung mengacu pada persamaan Hake (1998:3) yaitu. $<\mathrm{g}>$

Keterangan: $\langle\mathrm{g}\rangle=$ Gain ternormalisasi $\mathrm{Sf}=$ Skor post-test $\mathrm{Si}=$ Skor pre-test.

2) Gain ternormalisasi dijumlahkan untuk semua mahasiswa dan ditentukan rataratanya.

3) Kategori efektifitas pengembangan produk bahan ajar dan penilaian otentik mata kuliah pendidikan IPA SD menggunakan klasifikasi Hake (1998: dapat dilihat pada tabel berikut. 
Tabel 2.

Efektifitas Produk Pengembangan

\begin{tabular}{|c|l|c|}
\hline No & \multicolumn{1}{|c|}{ Gain } & Kategori \\
\hline 1 & $\mathrm{~g} \geq 0,7$ & Tinggi \\
\hline 2 & $0,7>g \geq 0,3$ & Sedang \\
\hline 3 & $\mathrm{~g}<0,3$ & Rendah \\
\hline
\end{tabular}

\section{HASIL DAN PEMBAHASAN}

\section{Hasil Pengembangan Produk Awal}

Hasil pengembangan produk awal bahan ajar dan penilaian otentik mata kuliah pendidikan IPA Sekolah Dasar pada mahasiswa jurusan PGSD tingkat 1 meliputi beberapa tahap pengembangan awal sebagai berikut.

\section{Studi Pendahuluan}

Studi pendahuluan dilakukan peneliti dengan menganalisis silabus mata kuliah pendidikan IPA SD. Dalam analisis yang dilakukan, ditemukan berbagai kekurangan dan ketidaksesuaian antara bahan ajar dengan silabus mata kuliah pendidikan IPA SD. Kebutuhan pada materi dan penilaian yang disajikan dalam bahan ajar Pendidikan IPA masih dirasa sangat kurang, kekurangan terdapat pada materi dan penilaian otentik yang belum tersajikan secara maksimal.

2. Perencanaan (Planning)

Tahap perencanaan dilakukan peneliti dengan menyusun rancangan pengembangan bahan ajar dan penilaian IPA berdasarkan kelemahan-kelemahan yang ditemukan pada studi pendahuluan terhadap bahan ajar yang tersedia.

3. Pengembangan produk awal

Pada tahap pengembangan produk awal peneliti menetapkan draft dan format bahan ajar meliputi cover bahan ajar, daftar isi, materi dan penilaian otentik mata kuliah pendidikan IPA SD yang meliputi 8 bab materi dan penilaian otentik pendidikan IPA SD sesuai dengan silabus mata kuliah pendidikan IPA SD serta daftar pustaka. Produk awal yang sudah dikembangkan kemudian divalidasi oleh ahli materi IPA dan ahli evaluasi IPA. Adapun pemaparan hasil validasi bahan materi dan instrumen penilaian itentik IPA bahan ajar pendidikan IPA SD disajikan sebagai berikut:

1) Hasil Validasi Bahan Ajar oleh Ahli IPA Hasil validasi penilaian materi dan instrumen penilaian IPA produk pengembangan bahan ajar pendidikan IPA SD meliputi ahli materi IPA dan ahli evaluasi IPA. Dimana hasil data validasi dan penilaian produk pengembangan ini merupakan penilaian para ahli, baik dari segi bahan ajar maupun instrumen penilaian otentik pendidikan IPA SD untuk mahasiswa PGSD. Berikut ini disajikan data hasil validasi produk oleh ahli materi IPA dan evaluasi IPA serta hasil penilaian produk oleh guru akan dipaparkan sebagai berikut.

2) Validasi Ahli Materi dan Ahli Evaluasi IPA Hasil validasi ahli materi IPA didapatkan perolehan hasil dengan jumlah nilai 70 dari 18 indikator pembelajaran yang dinilaidengan rentang skor 1-5 untuk penilaian produk pengembangan, sehingga diperoleh nilai dengan rata-rata 3,8 dari seluruh penilaian indikator pada materi IPA, kemudian nilai ratarata 3,8 dilakukan perhitungan kriteria, maka didapatkan hasil dengan kategori Baik pada produk materi IPA yang dikembangkan. Sedangkan hasil validasi ahli instrumen evaluasi IPA, didapatkan hasil dengan jumlah nilai 49 dari 12 indikator pembelajaran yang di 
nilai dengan rentang skor 1-5 untuk penilaian produk pengembangan, pada instrumen evaluasi IPA diperoleh rata-rata nilai 4,08 dari keseluruhan Indikator penilaian yang disajikan pada instrumen evaluasi IPA, setelah dilakukan perhitungan kriteria pada nilai ratarata 4,08 hasil kreteria yang di dapat berkategori "Baik" pada produk instrumen evaluasi IPA yang dikembangkan.

\section{Hasil Uji Coba Produk}

Hasil data yang diperoleh dari uji coba produk penelitian yang dilakukan pada pengembangan bahan ajar dan penilaian otentik pada mata kuliah pendidikan IPA SD yaitu uji coba lapangan terbatas dan Uji pelaksanaan lapangan yang dilaksanakan pada bulan Juni-Juli 2017 di Universitas Kuningan pada jurusan PGSD. Berikut ini disajikan hasil perolehan data selama pelaksanaan uji coba produk.

\section{Hasil Uji Coba Terbatas \\ Uji coba lapangan terbatas ini} dimaksudkan untuk mendapatkan masukan dan saran pada produk yang dikembangkan pada kebutuhan mahasiswa jika terdapat kesalahan dan kelemahan-kelemahan yang ada pada produk pada saat Uji coba awal terhadap kondisi di lapangan. Uji coba terbatas ini di lakukan pada seluruh mahasiswa kelas B tingkat 1 jurusan PGSD Universitas Kuningan dengan subjek penelitian sebanyak 29 mahasiswa. Uji coba terbatas ini dilaksanakan dengan membagikan produk yang dikembangkan kepada masing-masing mahasiswa dibantu oleh dosen pengampu mata kuliah pendidikan IPA SD untuk melaksanakan proses pembelajaran dengan menggunakan produk pengembangan bahan ajar dan penilaian otentik pada mata kuliah pendidikan IPA SD.
Berdasarkan 2 diatas maka diketahui respon mahasiswa terhadap kelayakan produk pengembangan bahan ajar dan penilaian otentik mata kuliah pendidikan IPA SD. Berikut ini pemaparan hasil respon mahasiswa berdasarkan tabel di atas yaitu diperoleh hasil dengan rata-rata yang memberikan respon Sangat Baik sebesar 26,2\%, respon peserta didik pada kategori Baik dengan presentase paling besar dengan 53,2\%, respon peserta didik yang diberikan pada kategori Cukup baik dengan presentase $17,5 \%$, sedangkan untuk respon kurang dengan presentasi $0,4 \%$ dan kurang sekali yaitu 2,8\%. Berdasarkan hasil yang diperoleh dari respon peserta didik diatas didapatkan hasil respon yang positif terhadap kelayakan pengembangan bahan ajar, dimana kreteria penilaian yang positif pada respon kelayakan mahasiswa adalah minimal 53,2\% peserta didik pada respon baik.

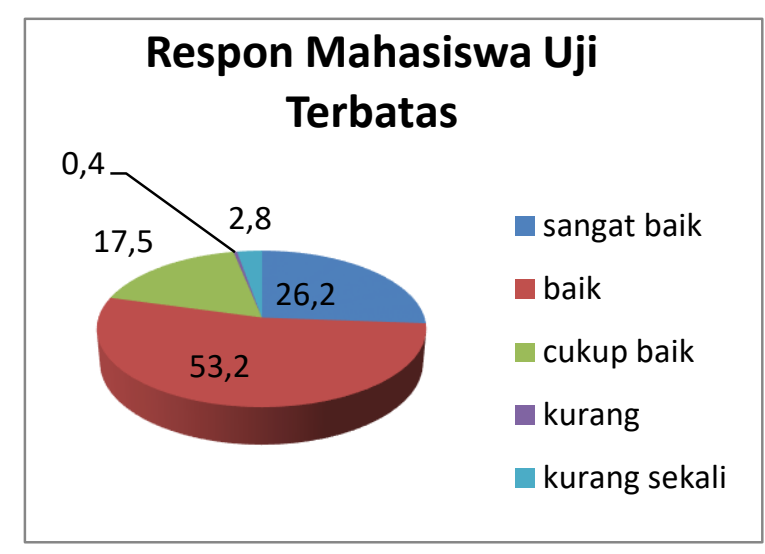

Gambar 2. Diagram Hasil Mahasiswa pada Uji Coba Terbatas

\section{Hasil Uji Pelaksanaan Lapangan.}

Uji pelaksanaan lapangan dilakukan untuk mendapatkan data hasil produk setelah dilakukan revisi pada tahap uji coba terbatas, apakah produk yang dikembangkan sesuai dengan kebutuhan mahasiswa atau tidak. Hasil uji lapangan ini diambil dari seluruh mahasiswa di 3 kelas tingkat 1 jurusan PGSD Universitas Kuningan yaitu kelas A, D, dan E 
dengan subyek kelas A 35 mahasiswa, kelas D 35 mahasiswa dan kelas E yaitu 29 mahasiswa. Sebelum uji pelaksanaan lapangan dilaksanakan dengan menggunakan produk pengembangan, peneliti melakukan penggambilan data pre-tes untuk melihat kemampuan awal mahaswiswa sebelum menggunakan produk yang dikembangkan.

Setelah pengambilan data pretes, selanjutnya dalam uji pelaksanaan lapangan adalah membagikan produk pengembangan bahan ajar dan penilaian otentik mata kuliah pendidikan IPA SD yang telah di revisi pada uji coba terbatas kepada 29 mahasiswa di kelas B peserta untuk digunakan selama proses pembelajaran. Selama proses pembelajaran peneliti melakukan penilaian kepada peserta didik pada aspek keterampilan (skill) dan sikap (atittude) peserta didik selama proses pembelajaran mengunakan produk pengembangan. Pada kegiatan akhir peneliti mengambil data post-tes dengan membagikan soal dengan kisi-kisi sama dengan soal pre-test untuk mengukur efektifitas kemampuan mahasiswa setelah menggunakan produk pengembangan bahan ajar dan penilaian otentik mata kuliah pendidikan IPA SD. Adapun hasil data selama proses pembelajaran selama uji pelaksanaan lapangan adalah sebagai berikut.

\section{Data hasil Pre-test dan Post-test}

Data Pre-tes diambil pada seluruh mahasiswa di kelas A, D, dan E PGSD Universitas Kuningan pada tingkat 1 untuk menggukur kemampuan awal peserta didik sebelum menggunakan produk pengembangan bahan ajar dan penilaian otentik mata kuliah pendidikan IPA SD dengan disaksikan dosen pengampu dan peneliti. Sedangkan data Posttest diambil setelah proses pembelajaran selesai dengan menggunakan produk pengembangan bahan ajar dan penilaian otentik mata kuliah pendidikan IPA SD yang digunakan untuk mengukur peningkatan yang dicapai peserta didik setelah menggunakan produk pengembangan yang nantinya akan dihitung dengan konversi nilai antara data Pretes dan Post-tes untuk melihat efektifitas peningkatan kemampuan yang terjadi.

Berdasarkan data pretes dan posttest diatas dapat diketahui kemampuan awal peserta didik didapatkan nilai rata-rata 31,59 sedangkan kemampuan setelah menggunakan produk pengembangan didapatkan nilai dengan rata-rata 78,27. Berdasarkan rata-rata posttes dan pretest terdapat peningkatan nilai rata-rata 46,68 setelah menggunakan produk pengembangan. Sedangkan hasil yang diperoleh pada pretes dan posttest dengan perhitungan gain score pada aspek kreteria di ketahui sebanyak 74 mahasiswa dalam kategori "Tinggi" dan terdapat 25 mahasiswa pada kategori "Sedang" sedangkan mahasiswa dalam kategori "Rendah" yaitu 0, dalam peningkatan hasil belajar mengunakan produk pengembangan.

Berikut ini disajikan diagram perolehan hasil klasifikasi gain score peserta didik uji pelaksanaan lapangan pada gambar 3 berikut.

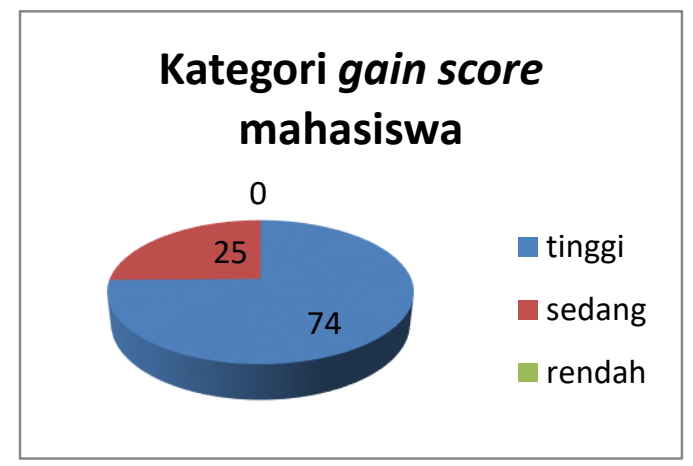

Gambar 3. Diagram perolehan gain score pada uji pelaksanaan lapangan

Berdasarkan perhitungan nilai gain score diperoleh rata-rata sebesar 0,71 dari 99 peserta didik. Berdasarkan pengkategorian hasil 
analisis gain score pada tabel perhitungan Hake maka nilai 0,71 di kategorikan Tinggi. Dengan hasil yang diperoleh maka dapat disimpulkan bahwa produk yang dikembangkan sangat efektif dalam proses pembelajaran.

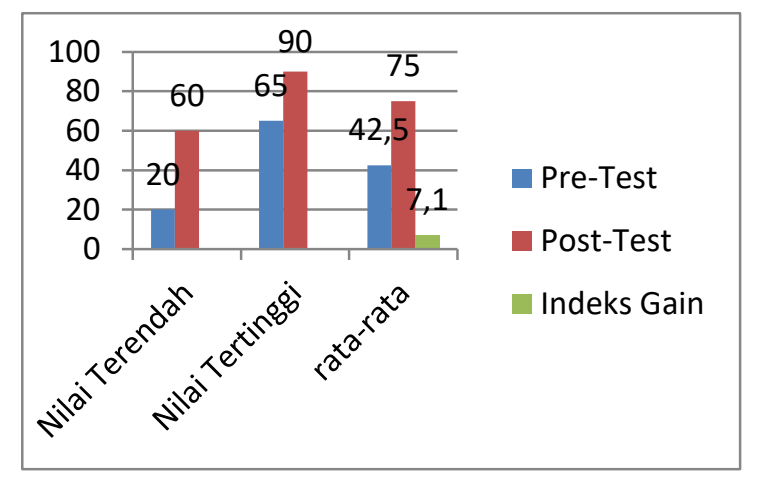

Gambar 4. Diagram pretes dan posttest

\section{Hasil Observasi Sikap dan Keterampilan Peserta Didik}

Selain hasil pretes dan post test, data yang diperoleh untuk melihat aspek keefektifan pengembangan bahan ajar dan penilaian otentik mata kuliah pendidikan IPA SD pada aspek sikap (Atittude) dan keterampilan (knowledge) adalah melalui observasi langsung selama proses pembelajaran menggunakan produk yang dikembangkan. Berikut ini adalah hasil observasi selama uji coba pelaksanaan lapangan di kelas A, D, dan E secara umum didapatkan hasil yang baik, salah satunya ditunjukan dengan rasa hormat dan keaktifan yang diperlihatkan mahasiswa pada saat mendengarkan dan memperhatikan dosen pada saat memberikan arahan tentang penggunaan bahan ajar yang telah di pegang setiap mahasiswa dan menjelaskan setiap materi pembelajaran.

\section{Hasil Angket Respon Mahasiswa pada Uji Coba Lapangan}

Pengambilan data respon peserta didik dalam uji coba pelaksanaan lapangan ini bertujuan untuk menggetahui respon dari mahasiswa terhadap kelayakan produk yang dikembangkan terhadap kebutuhan mahasiswa itu sendiri, apakah produk yang dikembangkan sesuai dengan kebutuhan mahasiswa atau tidak. Hasil angket respon mahasiswa uji pelaksanaan lapangan ini diambil pada seluruh mahasiswa di 3 kelas tingkat 1 jurusan PGSD Universitas Kuningan yaitu kelas A, D, dan E dengan subyek kelas A 35 mahasiswa, kelas D 35 mahasiswa dan kelas E yaitu 29 mahasiswa.

Berdasarkan hasil uji coba lapangan dari tiga kelas, didapatkan hasil rata-rata respon mahasiswa sebagai berikut, mahasiswa yang memberikan respon Sangat Baik sebesar $27,2 \%$, respon peserta didik pada kategori Baik dengan presentase rata-rata 54,91\%, untuk respon peserta didik yang diberikan pada kategori Cukup Baik dengan presentase $16,27 \%$, sedangkan untuk respon peserta didik dengan kategori Kurang sebesar 0,66\% dan Kurang Sekali sebesar 0,99\%.

Revisi produk pengembangan dilakukan berdasarkan masukan dan saran dari para ahli dan mahasiswa. Revisi produk pengembangan dilakukan berdasarkan kebutuhan mahasiswwa terhadap temuan yang didapatkan selama uji coba lapangan baik uji terbatas maupun pelaksanaan lapangan pada mahasiswa jurusan PGSD Universitas Kuningan tingkat 1 kelas A, B, D, dan E.

\section{Revisi Produk Pertama}

Revisi tahap pertama ini didapatkan dari hasil uji coba awal pada saat validasi produk ahli materi IPA dan validator evaluasi IPA. Hasil validasi ini berupa penilaian, masukan perbaikan, saran dan kritik produk pengembangan bahan ajar dan penilaian otentik mata kuliah pendidikan IPA SD. Revisi produk awal yang di lakukan menjadi dasar untuk menggembangkan poduk yang layak 
untuk di uji cobakan di lapangan. Adapun masukan validator ahli materi IPA dan ahli evaluasi IPA guna perbaikan-perbaikan pada produk pengembangan bahan ajar dan penilaian otentik mata kuliah pendidikan IPA SD adalah sebagai berikut.

a) Perbaikkan tata tulis pada bahan ajar yang dikembangkan.

b) Disetiap awal bab materi disertakan pendahuluan.

c) Perbaikan tata tulis pada setiap soal yang ada di masing-materi.

d) Mempertimbangkan penilaian diri atau teman sejawat pada setiap soal dalam materi masing-masing.

e) Dukung gambar yang menarik dan relevan masih perlu ditambah pada setiap sub bagian penilaian/ materi

\section{Revisi produk kedua}

Revisi produk tahap kedua dilakukan pada saat uji coba lapangan secara terbatas yang di uji cobakan pada seluruh mahasiswa kelas B tingkat 1 jurusan PGSD Universitas Kuningan yang berjumlah 29 mahasiswa. Masih ada beberapa penulisan tempat belum sesuai tata bahasa, masih ditulis dengan huruf kecil, mohon dikoreksi.

a) Mohon dipertimbangkan untuk membuat sub-bab agar lebih mempermudah mahasiswa dalam mengetahui batasanbatasan bab.

b) Ditambahkan materi yang lebih luas.

c) Terlalu banyak menggunakan bahasa asing.

\section{Revisi produk ketiga.}

Revisi produk tahap ketiga ini dilakukan berdasarkan masukan, saran dan komentar produk pengembangan pada saat uji pelaksanaan lapangan secara lebih luas, yang di uji cobakan pada subjek seluruh mahasiswa di 3 kelas tingkat 1 jurusan PGSD Universitas Kuningan yaitu kelas A, D, dan E dengan subyek kelas A 35 mahasiswa, kelas D 35 mahasiswa dan kelas E yaitu 29 mahasiswa untuk menghasilkan produk final pengembangan bahan ajar dan penilaian otentik mata kuliah pendidikan IPA SD.

Berikut adalah beberapa masukan produk pengembangan bahan ajar dan penilaian otentik mata kuliah pendidikan IPA SD.

a) Buku pengembangan bahan ajar dan penilaian otentik mata kuliah pendidikan IPA SD sangat membantu dan mempermudah mahasiswa dalam proses pembelajaran karena penyajian materi, instrumen penilaian dan penilaiannyapun sudah disajikan dan sesuai dengan kebutuhan mahasiswa.

b) Penilaian sudah dikembangkan sesuai dengan aspek pengetahuan, sikap dan keterampilan sesuai dengan harapan, namun perlu adanya pengemasan yang baik seperti cover dan gambar agar bahan ajar ini lebih menarik minat pembaca.

c) Tolong penulisan tata tulis di perbaiki

d) Materi dalam setiap bab sudah mewakili kebutuhan mahasiswa, namun .apabila di perluas dengan bahasa yang menarik akan menjadi produk yang lebih baik.

\section{Kajian Produk Akhir}

Penelitian pengembangan ini bertujuan untuk menggembangkan bahan ajar dan penilaian otentik mata kuliah pendidikan IPA SD yang layak dan efektif sesuai kebutuhan mahasiswa sesuai dengan silabus yang digunakan. Terdapat beberapa tahap utama yang dilakukan peneliti dalam pengembangan materi dan instrument bahan ajar dan penilaian otentik mata kuliah pendidikan IPA SD untuk mendapatkan produk final, yang pertama 
adalah uji coba awal dengan validasi ahli materi IPA dan ahli evaluasi IPA untuk mendapatkan produk awal yang layak untuk di ujicobakan dilapangan, yang kedua adalah mengumpulkan temuan pada uji lapangan secara terbatas pada mahasiswa di kelas B tingkat 1 jurusan PGSD Universitas Kuningan dengan subjek 29 peserta didik, dan yang ketiga adalah temuan pada saat uji pelaksanaan lapangan seluruh mahasiswa di 3 kelas tingkat 1 jurusan PGSD Universitas Kuningan yaitu kelas A, D, dan E dengan subjek kelas A 35 mahasiswa, kelas D 35 mahasiswa dan kelas E yaitu 29 mahasiswa, dari beberapa tahapan utama produk pengembangan tersebut maka dihasilkan produk final.

\section{Bahan Ajar dan Penilaian Otentik Mata Kuliah Pendidikan IPA SD}

Berdasarkan hasil penilaian yang diperoleh dari ahli materi IPA bahwa materi IPA pada bahan ajar dan penilaian otentik mata kuliah pendidikan IPA SD yang dikembangkan dalam kategori Baik dengan perolehan nilai rata-rata 3,9 dalam skala 5 . Sedangkan hasil penilaian yang diperoleh dari ahli evaluasi IPA juga menunjukan hasil dalam kategori Baik, ini bisa dilihat dari perolehan nilai rata-rata 4,08 dalam skala 5 .

Berdasarkan hasil penilaian yang didapatkan pada saat uji coba terbatas yang dilaksanakan di kelas B mahasiswa jurusan PGSD Universitas Kuningan diketahui respon mahasiswa terhadap kelayakan produk pengembangan bahan ajar dan penilaian otentik mata kuliah pendidikan IPA SD diperoleh hasil dengan rata-rata yang memberikan respon Sangat Baik sebesar $26,2 \%$, respon peserta didik pada kategori Baik dengan presentase paling besar dengan 53,2\%, respon peserta didik yang diberikan pada kategori Cukup baik dengan presentase 17,5\%, sedangkan untuk respon kurang dengan presentasi 0,4\% dan kurang sekali yaitu 2,8\%. Berdasarkan hasil yang diperoleh dari respon peserta didik diatas didapatkan hasil respon yang positif terhadap kelayakan pengembangan bahan ajar, dimana kreteria penilaian yang positif pada respon kelayakan mahasiswa adalah minimal 53,2\% peserta didik pada respon baik.

Sedangkan hasil penilaian yang didapatkan pada saat uji coba lapangan yang dilaksanakan di kelas A, D, dan E mahasiswa jurusan PGSD Universitas Kuningan. Berikut hasil uji coba lapangan yang didapatkan dari mahasiswa kelas A diketahui respon mahasiswa terhadap kelayakan produk pengembangan bahan ajar dan penilaian otentik mata kuliah pendidikan IPA SD diperoleh hasil dengan rata-rata yang memberikan respon Sangat Baik sebesar $24,5 \%$, respon peserta didik pada kategori Baik dengan presentase rata-rata $61,7 \%$, untuk respon peserta didik yang diberikan pada kategori Cukup Baik dengan presentase $12,1 \%$, sedangkan untuk respon peserta didik dengan kategori Kurang sebesar 0,8\% dan Kurang Sekali sebesar 0\%. Berdasarkan hasil yang diperoleh dari respon peserta didik diatas pada keterbacaan produk pengembangan didapatkan hasil respon mahasiswa yang positif karena kreteria respon yang positif pada respon mahasiswa 61,7 pada respon Baik.

Sedangkan hasil uji coba lapangan yang didapatkan dari mahasiswa kelas D diketahui respon mahasiswa terhadap kelayakan produk pengembangan bahan ajar dan penilaian otentik mata kuliah pendidikan IPA SD diperoleh hasil dengan rata-rata yang memberikan respon Sangat Baik sebesar 30\%, respon peserta didik pada kategori Baik dengan presentase rata-rata $49,8 \%$, untuk respon peserta didik yang diberikan pada 
kategori Cukup Baik dengan presentase 20,3\%, sedangkan untuk respon peserta didik dengan kategori Kurang sebesar 7,1\% dan Kurang Sekali sebesar 2,9\%. Berdasarkan hasil yang diperoleh dari respon peserta didik diatas pada keterbacaan produk pengembangan didapatkan hasil respon mahasiswa yang positif karena kreteria respon yang positif pada respon mahasiswa 49,8\% pada respon Baik.

Kemudian hasil uji coba lapangan di kelas terakhir yaitu kelas $\mathrm{E}$ diketahui respon mahasiswa terhadap kelayakan produk pengembangan bahan ajar dan penilaian otentik mata kuliah pendidikan IPA SD diperoleh hasil dengan rata-rata yang memberikan respon Sangat Baik sebesar $26,2 \%$, respon peserta didik pada kategori Baik dengan presentase rata-rata 53,2\%, untuk respon peserta didik yang diberikan pada kategori Cukup Baik dengan presentase $17,5 \%$, sedangkan untuk respon peserta didik dengan kategori Kurang sebesar 0,4\% dan Kurang Sekali sebesar 2,8\%. Berdasarkan hasil yang diperoleh dari respon peserta didik diatas pada keterbacaan produk pengembangan didapatkan hasil respon mahasiswa yang positif karena kreteria respon yang positif pada respon mahasiswa 53,2\% pada respon Baik.

Dari perolehan nilai tersebut tersebut maka kelayakan bahan ajar dan penilaian otentik mata kuliah pendidikan IPA SD yang di kembangkan sudah memenuhi syarat kelayakan untuk di Impelementasikan pada proses pembelajaran di lapangan.

\section{SIMPULAN DAN SARAN}

Berdasarkan hasil penelitian dan analisis data maka diperoleh kesimpulan dalam penelitian pengembangan ini sebagai berikut.
1. Hasil pengembangan bahan ajar dan penilaian otentik mata kuliah pendidikan IPA SD terbukti layak berdasarkan data hasil penelitian. Berdasarkan uji coba lapangan dari tiga kelas, didapatkan hasil rata-rata mahasiswa yang memberikan respon Sangat Baik sebesar 27,2\%, respon peserta didik pada kategori Baik dengan presentase rata-rata $54,91 \%$, untuk respon peserta didik yang diberikan pada kategori Cukup Baik dengan presentase 16,27\%, sedangkan untuk respon peserta didik dengan kategori Kurang sebesar 0,66\% dan Kurang Sekali sebesar 0,99\%.

2. Dapat diketahui bahwa bahan ajar dan penilaian otentik mata kuliah pendidikan IPA SD yang dikembangkan terbukti efektif, Dimana hasil pada perhitungan gain score pada aspek kreteria di ketahui sebanyak 74 mahasiswa dalam kategori "Tinggi" dan terdapat 25 mahasiswa pada kategori "Sedang" sedangkan mahasiswa dalam kategori "Rendah" yaitu 0 . Sedangkan berdasarkan pada perhitungan nilai gain score diperoleh rata-rata sebesar 0,71 dari 99 peserta didik. Berdasarkan pengkategorian hasil analisis gain score pada tabel perhitungan Hake maka nilai 0,71 di kategorikan Tinggi. Dengan hasil yang diperoleh maka dapat disimpulkan bahwa produk yang dikembangkan sangat efektif dalam proses pembelajaran.

\section{Pemanfaatan Produk}

1. Produk pengembangan bahan ajar dan penilaian otentik mata kuliah pendidikan IPA SD dapat digunakan oleh dosen dan mahasiswa untuk referensi tambahan dalam proses kegiatan pembelajaran khususnya dalam mata kuliah pendidikan IPA SD. 
2. Produk pengembangan bahan ajar dan penilaian otentik mata kuliah pendidikan IPA SD dapat digunakan sebagai referensi untuk pengembangan bahan ajar mata kuliah pendidikan IPA SD lebih lanjut.

\section{DAFTAR PUSTAKA}

Borg. L,E, \& Gall, M.D (1983) Edcational reseach. (4thed). New York: Logman.

Dick, W., Carey, L.\& Carey, J.O. (2009) .The systematic design of instruction (7th ed). Boston: Allyn and Bacon.

Hake, R.R. (1998). Interactive engagement vs traditional methods: A six-thousandstudent survey of mechanics test data for introductory physics. Departement of physics. American Journal of Physics,(1998) hlm. 1-26.

Kunandar. (2013). Penilaian Autentik Penilaian Hasil Belajar Peserta Didik Berdasarkan Kurikulum 2013. Jakatra: Raja Grafindo persada.

Mendikbud. (2013). Standar Penilaian Pendidikan. Jakarta: Mentri Pendidikan dan Kebudayaan Republik Indonesia.

Manokore, V. \& Williams, M. (2012). Middle school students' reasoning about biological inheritance: students' resemblance theory. International Journal of Biology Education, 2(1), pp. 1-31.

Martin, R., Sexton, C.,Ffranklin., \& Gerlovich, J. (2005). Teaching science for all childern, inquiry metods for constructing understanding, New Jersey: Pearson Education.

Morrison, G.S. (2012). Dasar-dasar Pendidikan Anak Usia Dini (PAUD) (Edisi Terjemahan Suci Romadhona \& April Widiastuti). New Jersey: Pearson Merill Prentice Hall. (Buku asli diterbitkan tahun 2008).

Nitko, A.J \& Brookhart. (2007). Educational Assesment of Student. New York: Pearson Education Inc.

Widoyoko, Eko Putro. (2009). Evaluasi Program Pembelajaran. Yogyakarta: Pustaka Pelajar. 